\title{
Using Instructional Time and Race/Ethnicity to Predict Social Studies Accountability Test Results
}

Kenneth E. Vogler, EdD

University of South Carolina, Columbia, South Carolina, United States

(iD https://orcid.org/0000-0002-0428-0789

Susan Schramm, PhD

University of South Carolina, Columbia, South Carolina, United States

(iD) https://orcid.org/ 0000-0002-4774-4686

Audrey Allan, PhD

Winthrop University, Rock Hill, South Carolina, United States

Jake D. Parler, MS

University of South Carolina, Columbia, South Carolina, United States

Contact: kvogler@mailbox.sc.edu

\section{Abstract}

This study investigated the relationship among the variables instructional time configuration, gender, race/ethnicity, and poverty to predict the academic performance of seventh-grade students on a statemandated social studies accountability test. Results of 24,919 seventh-grade student social studies test scores from 117 middle schools, as well as a survey given to principals of the same 117 middle schools, were analyzed. A hierarchical multiple regression analysis showed that when controlling for poverty, the variables instructional time configuration and race/ethnicity were significant, explaining $11 \%$ of the variation in student social studies accountability test results; a small effect. Analysis of variance (ANOVA) and analysis of covariance (ANCOVA) were also used to illuminate the relationship of these variables on accountability test performance.

Keywords: hierarchical multiple regression, instructional time, scheduling, social studies, testing

Date Submitted: March 4, 2020 | Date Published: July 27, 2020

\section{Recommended Citation}

Vogler, K. E., Schramm, S., Allan, A., \& Parler, J. D. (2020). Using instructional time and race/ethnicity to predict social studies accountability test results. Journal of Educational Research and Practice, 10, 199-220.

https://doi.org/10.5590/JERAP.2020.10.1.14

\section{Introduction}

How to make the best use of instructional time has stymied educational leaders, teachers, and policymakers for the last 300 years (Zepeda \& Mayers, 2006). Most states have laws that define the minimum number of days per year and hours per day that students must attend school, and the minimum amount of instructional

Note: The survey instrument used in this study is available upon request from Kenneth Vogler, Department of Instruction and Teacher Education, University of South Carolina, Columbia, SC 29208. Email: kvogler@mailbox.sc.edu. 
time. However, the way time is allocated is neither defined nor prescribed and thus gives school leaders considerable flexibility in instructional time configurations based specifically on their own prioritized instructional needs and non-instructional activities (Zepeda \& Mayers, 2006). This flexibility, combined with a lack of specific guidelines regarding instructional time configurations, has generated incessant criticism and been a driving issue in a succession of movements to reform education (Powell et al., 1985).

The latest focus on instructional time configuration reform began in the early 1980 ; informed by publications such as A Nation at Risk: The Imperative for Education Reform (National Commission on Excellence in Education, 1983), A Place Called School: Prospects for the Future (Goodlad, 1984), and Prisoners of Time: Report of the National Education Commission on Time and Learning (National Education Commission on Time and Learning, 1994), elected leaders and educational reformers demanded the restructuring of instructional time. In response, an unprecedented wave of schools moved away from traditional schedules and adopted different configurations touted as a way to maximize instructional time (Canady \& Rettig, 1996). For example, in Texas, the number of high schools using block scheduling rose from $4 \%$ to over $40 \%$ in a 4 -year span between 1992 and 1995 (Texas Education Agency, 1999).

Proponents of block scheduling see it as an instrument to maximize instructional time by (1) reducing the number of students for whom teachers must prepare and with whom teachers interact each day and/or each term; (2) reducing the number of classes, and assignments, tests, and projects that teachers must address during any single day of a term; (3) reducing the fragmentation in traditional schedules, a complaint especially pertinent to classes requiring extensive practice and laboratory work; (4) providing teachers with lots of time that allow and encourage the use of active teaching strategies promoting greater student involvement; and (5) allowing students variable amounts of time for learning without lowering standards and without punishing those who need more or less time to learn (Hottenstein, 1998). In addition, researchers Canady and Rettig (2000) noted fewer school discipline problems, higher achievement rates for students, and more school productivity as reasons why educational leaders adopted block schedules.

The following are descriptions of the most commonly used instructional time configurations:

\section{Traditional Schedules}

Traditional schedules are those with "a fixed number of daily periods of uniform length, with delivery of instruction strictly adhering to departmental classifications” (Hackmann \& Valentine, 1998, p. 6). Traditional schedules generally contain from five to 10 instructional periods (Hackmann \& Valentine).

\section{Flexible Schedules}

Flexible schedules are characterized by a shift from fixed-time instructional periods (e.g., 40-50 minutes) towards longer instructional periods (e.g., 75-150 minutes). These extended amounts of time within flexible instructional time configurations are often associated with inquiry or constructivist pedagogies rather than didactic lecture (Bevevino et al., 1999; Daniel, 2007). The two most commonly used flexible instructional time configurations are known as block scheduling and alternate day class scheduling, or what is referred to as the A/B schedule (Daniel, 2007).

\section{Block Schedules}

Block scheduling uses blocks of time created from combining instructional time allotted for a traditionally scheduled period (45 minutes) into two or more combined periods (Gullatt, 2006; Hackmann, 2002). This can include periods of all the same length (e.g., 90 minutes) or can adjust the length of time devoted to each time block according to the instructional needs of students (e.g., core academic subjects such as math and language arts may be assigned longer blocks of time while subjects not considered core or academic such as physical education and art may be assigned shorter blocks of time). The length of time of a block can also vary from day to day and week to week. Common block instructional time configurations in middle level use what 
is referred to as $4 \times 4$ (four-by-four) schedules where students take four classes for half an academic year and then four different classes the second half of the academic year (Daniel, 2007).

\section{A/B Schedule}

Flexible instructional time configurations may also utilize an alternating day schedule. In this arrangement, classes may meet on an every-other-day basis with even-numbered and odd-numbered class periods meeting on alternating days (Hackmann, 2002). For example, students may attend one set of classes on certain days of the week and another set of classes on the remaining days.

\section{Impact of Accountability Testing on Social Studies}

Educational accountability is another reform effort designed to improve student achievement. Generally speaking, the reform has two parts: first, devise curriculum standards and expectations; and second, create assessments (accountability tests) designed to measure how well students meet the curriculum standards and expectations (student achievement) (Madaus \& Russell, 2009/2010). The federally mandated legislation the No Child Left Behind Act (NCLB, 2002) and continuing with the Every Student Succeeds Act (ESSA, 2015), has been at the forefront of this effort. However, the primary focus of the legislation is on the content areas of reading/language arts and mathematics. It does not mandate standardized testing in social studies nor does it include social studies in its school performance calculations. Because of this omission, the legislation has had a dramatic impact on social studies instruction. In addition, the adoption of Common Core State Standards in many states added even more pressure on teachers' curricular decisions. These more rigorous standards have caused teachers to focus additional attention on implementing and teaching the English Language Arts and Literacy Standards and Mathematics Standards at the expense of other subject areas (Alberti, 2012/2013).

Past studies show the pressure on schools to perform well in the tested subjects of reading/language arts, mathematics, and science impacts both the schedule (i.e., time allocated to instruction) and the actual amount of time spent teaching social studies (Abrams et al., 2003; Bailey et al., 2006; Burroughs et al., 2005; Heafner, 2018; Hong \& Hamot, 2020; Houser et al., 2017; Kavanagh \& Fisher-Ari, 2018; Leming et al., 2006; Lintner, 2006; Pace, 2012; Pascopella, 2005; Pedulla et al., 2003; Segail, 2003; VanFossen, 2005; Vogler, 2003; Vogler \& Virtue, 2007; vonZastrow \& Janc, 2004; Zamosky, 2008). Lintner (2006) found in a study of Kindergarten through fifth-grade social studies in South Carolina that "with such a tremendous emphasis being placed on reading, writing, and math, social studies has to fight for instructional time” (p. 3). Bailey et al. (2006) determined that, in Title I schools in the state of Alabama, the actual amount of instructional time spent on social studies in Kindergarten through fifth-grade self-contained classrooms confirmed the assault on social studies' instructional time reported by Lintner (2006). Bailey et al. (2006) also found that not only was the instructional time spent on social studies reduced in Alabama's elementary schools, but the amount of time actually spent on social studies on average was far less than the amount of time allocated by the school district and mandated by the state. In fact, some schools had weeks when social studies was not taught at all (Bailey et al., 2006).

\section{Academic Achievement Gap}

Past results of state-mandated accountability tests show wide gaps in academic achievement based on particular student variables (Baker, 2016; Clotfelter et al., 2009; Fryer \& Levitt, 2004, 2005; Kuhfeld et al., 2018; Murnane et al., 2006; Olszewski-Kubilius et al., 2018; Phillips et al., 1998; Reardon \& Portilla, 2015). Among these variables is race/ethnicity; specifically, Black-White (Burchinal et al., 2011; Fryer \& Levitt, 2004; 2006; Kuhfeld et al., 2018; Paschall et al., 2018; Reardon \& Portilla, 2015) and Hispanic-White (Hemphill \& Vanneman, 2011; Kuhfeld et al., 2018; Paschall et al., 2018; Reardon \& Galindo, 2009). Additionally, researchers have noted this achievement gap begins to appear during middle school (Davis \& Jordan 1996; Ford, 1992; Mickelson \& Greene, 2006; Olszewski-Kubilius et al., 2018). 
Poverty is another variable under scrutiny when discussing student achievement gaps in state-mandated tests (Alexander \& Jang, 2020; Baker, 2016; Clotfelter et al., 2009; Fernald et al., 2013; Harwell, 2018; Kuhfeld et al., 2018; Murnane et al., 2006; Olszewski-Kubilius et al., 2018; Phillips et al., 1998; Turner \& Spain, 2020). This, according to researchers, is because Black and Hispanic students are more likely to experience the negative effects of poverty (e.g., low household income and unemployed family members) than White students (Reeves et al., 2016). And, as discussed by Thompson and Suarez (2015), 25\% of Black families have zero or negative net worth, while only $9 \%$ of White families do. Additionally, it is quite likely that Black and Hispanic students in poverty face additional unidentified barriers than do White students in poverty (Kuhfeld et al., 2018). Clearly, these disparities justify the need to account for the variables of race/ethnicity and poverty in any model attempting to predict student test performance.

\section{South Carolina's Testing Program}

Before the national education accountability legislation, NCLB (2002), and its successor the ESSA (2015), the state legislature passed the South Carolina Education Accountability Act in 1998 which enacted a review process for evaluating K-12 schools in South Carolina (South Carolina Department of Education, 2009a). The primary instrument for measuring student progress according to this law was the Palmetto Achievement Challenge Test (PACT). In 1999, the PACT was first administered to students in grades 3-8 and scores were categorized as Advanced, Proficient, Basic, or Below Basic. The tests first included only sections in mathematics and English, but in spring 2003 the assessment was expanded to include science and social studies. However, in spring 2007 the state cut back on its testing program and introduced the census testing of social studies and science in grades four and seven; this meant only students in grades four and seven would be required to take both the social studies and science tests. For students in grades three, five, six, and eight, they would take either the social studies or science test but not both. In June 2008, the assessment system was renamed the Palmetto Assessment of State Standards (PASS). The only major difference between the PACT and the PASS was the categories used to report student scores. Whereas the PACT categorized student scores as Advanced, Proficient, Basic, or Below Basic, student scores on the PASS were to be reported as Exemplary, Met, or Not Met. Individual student scores on these tests would be used to help determine a ranking for the state's School Report Card that rates schools as Excellent, Good, Average, Below Average, and Unsatisfactory (South Carolina Department of Education, 2009a). In 2014, the PASS was changed to the South Carolina Palmetto Assessment of State Standards (SCPASS).

At the time this study was conducted, the PASS was the state's testing program and the social studies portion consisted of 45 items for third grade and up to 60 items for eighth grade. Each item was a 1-point, fouroption, multiple-choice question aligned to the standards for that particular grade level (South Carolina Department of Education, 2009a). In addition, the test contained 6 to 12 embedded field test items. These items were for test development purposes only and were not included in the calculation of student scores (South Carolina Department of Education, 2009a).

\section{Statement of the Problem}

The federally mandated NCLB and later ESSA legislation's focus on reading/language arts and mathematics testing outcomes has forced administrators and teachers to allocate more instructional time to these content areas at the expense of other content areas. However, 28 states, including South Carolina, still include social studies as part of their accountability system and mandate scores in this content area to be included as part of a school's review (Mullen \& Woods, 2018). If states expect students to score within a particular range in the area of social studies on the states' accountability tests, in spite of the pressure and focus on reading/language arts and mathematics, it stands to reason that they need to re-examine the ways in which instructional time is allocated vis-à-vis scheduling configurations to teach these content areas. 


\section{Purpose of Study}

The purpose of this study was to investigate the relationship among the variables instructional time configuration, gender, race/ethnicity, and poverty to predict the academic performance of seventh-grade students on a state-mandated social studies accountability test.

\section{Research Question}

The following is the study's research question:

How well do the variables instructional time configuration, gender, and race/ethnicity, while controlling for poverty, predict the academic performance of seventh-grade students on a state-mandated social studies accountability test?

The article begins with a description of the study's method and an examination of results, followed by a discussion of results in relation to the research question, and concludes with information about the study's limitations and directions for future research.

\section{Method}

The data to answer the research question was obtained through: (1) an examination of 2009 seventh-grade student PASS social studies test scores, (2) South Carolina Poverty Index data, ${ }^{1}$ and (3) the results of a survey instrument given to South Carolina middle-level principals designed to elicit information about the instructional time configuration used at their school.

\section{Archived PASS and Poverty Index Data}

The South Carolina State Department of Education (SCSDOE) archival data set for the 2009 spring administration of the social studies seventh-grade PASS test (school level, aggregate data only) was used in the present study. The data set was accessed from SCSDOE's PASS data website. In addition, Poverty Index data for 2009 was also retrieved from the SCSDOE's data website archives. Since the Poverty Index is a rating earned by each school, it was applied to each student based on the school attended. The Poverty Index was used to control for poverty (covariate).

\section{Survey Instrument}

A survey instrument was used to collect data on scheduling configurations and principals' perception data. The instrument asks for demographic information and includes 10 Likert item questions. The validity of the survey instrument was previously established through a longitudinal study that began in 2003. Survey questions were developed by university social studies education professors and reviewed by preservice elementary-level and middle level education teachers, practicing teachers, and other university faculty. The questions were edited to improve clarity, reduce bias, and guarantee consistency in interpretation. Survey questions were pilot tested with 25 preservice and 25 practicing teachers. The questions were then redesigned to accommodate recommendations in order to insure the validity of the instrument. Permission to use the

\footnotetext{
${ }^{1}$ The South Carolina Poverty Index is a calculation ensuring that student achievement among districts and schools across the state are being compared with districts and schools with similar student and demographic characteristics. The index is based on free and reduced-price lunch data and Medicaid eligibility data. It was developed in direct response to a mandate of the Code of Laws of South Carolina, Section 59-18-90o(C), which required the state to set criteria for academic performance ratings and performance indicators and to establish guidelines for statistical analysis regarding datareporting purposes.
} 
survey instrument and to modify questions for the present study was received from the developing researchers and the review board of the University of South Carolina.

An internal consistent reliability analysis was used to assess the reliability of scores yielded by the survey instrument. Cronbach's alpha was used to assess score reliability of the survey instrument. The survey instrument had an alpha of .73, this is slightly above the .70 suggested as being indicative of adequate score reliability (Nunnally \& Bernstein, 1994).

\section{Sample}

The target population for this study was seventh grade students attending traditional public middle-level schools (excluding charter schools and schools with multiple elementary and secondary grades) in South Carolina who took the PASS social studies test in Spring 2009. ${ }^{2}$ There were 210 schools in 73 school districts that met these criteria; 117 schools representing 58 districts agreed to participate. Meaning, there was a $56 \%$ response rate from schools eligible to participate in the study and a $79 \%$ response rate from the eligible districts in the state. The participating schools in this study are representative of the state in terms of percentage rural and urban and student characteristics of race/ethnicity, income, and past performance on state accountability assessments (South Carolina Department of Education, 2009b).

The principals of the 117 participating middle-level schools completed the survey instrument. Individual student scores, gender, and race/ethnicity were derived from the 2009 spring social studies seventh-grade PASS test report. The total sample size for this study was 24,919 students.

Table 1 displays descriptive statistics about the sample, including size, percentage, mean, and standard deviation of the variables instructional time configuration, gender, and race.

The most frequently used instructional time configurations were traditional 45-60 minute all year (63.7\%) and 61-79 minute block all year (23.1\%). These were followed by 80-90 minute block all year (6.9\%) and A/B 80-90 minute block all year (5.4\%). One school used an A/B 45-60 minute block all-year configuration ( $\mathrm{N}=$ $131, \%=.5)$ and another school used an unnamed "other" instructional time configuration $(\mathrm{N}=106, \%=.4) .^{3}$ In regards to the independent variable gender, the sample population was made up of $51.5 \%$ males and $48.5 \%$ females. Among the different race/ethnicities of students, White (58.7\%) and Black (34.4\%) comprised 93.1\% of the total sample population, followed by Hispanic (4.8\%), Asian (1.5\%), and American Native/Alaskan $(.3 \%) .4$

\footnotetext{
${ }^{2}$ Seventh grade was the only middle-level grade in which all students were tested in social studies. Students were randomly assigned to be tested in either science or social studies in all the other middle-grade levels.

${ }^{3}$ Students in schools using an A/B 45-6o min block all-year instructional time configuration and an unnamed "other" instructional time configuration were removed from further calculations because they made up only $.9 \%$ of the total sample population.

${ }^{4}$ Asian and American Native/Alaskan students were excluded from further calculations because they collectively comprised only $1.8 \%$ of the total sample population.
} 
Table 1: Descriptive Statistics of Student Social Studies Accountability Test Results by Instructional Time Configuration, Gender, and Race/Ethnicity

\begin{tabular}{lcccc}
\hline Variable & $\boldsymbol{N}$ & $\mathbf{\%}$ & $\boldsymbol{M}$ & $\boldsymbol{S D}$ \\
\hline Instructional Time Configuration & & & & \\
Trad 45-60 min all year & & & & \\
61-79 min blk all yearb & 15928 & 63.7 & 617.23 & 48.95 \\
80-90 min blk all yearc & 5780 & 23.1 & 621.34 & 51.59 \\
A/B 80-90 min blk all year & 1710 & 6.9 & 609.36 & 47.28 \\
A/B 45-60 min blk all yeare & 1336 & 5.4 & 624.97 & 49.67 \\
Other & 131 & 0.5 & 599.05 & 38.25 \\
Gender & 106 & 0.4 & 612.98 & 48.45 \\
Male & & & & \\
Female & 12859 & 51.5 & 621.48 & 53.66 \\
Race/Ethnicity & 12132 & 48.5 & 614.23 & 44.57 \\
White & & & & \\
Black & 14670 & 58.7 & 628.55 & 50.69 \\
Hispanic & 8600 & 34.4 & 598.72 & 40.93 \\
Asian & 1196 & 4.8 & 612.39 & 45.19 \\
American Native/Alaskan & 371 & 1.5 & 652.67 & 23.34 \\
Missing & 72 & 0.3 & 622.96 & 45.72 \\
\hline
\end{tabular}

Note. ${ }^{2} 73$ schools used this configuration; ${ }^{\mathrm{b}} 25$ schools used this configuration; ${ }^{\mathrm{c}} 10$ schools used this configuration; $\mathrm{d} 7$ schools used this configuration; ${ }^{\mathrm{e}} \mathbf{1}$ school used this configuration; $\mathrm{f}_{1}$ school used this configuration.

\section{Data Analysis}

A number of analyses of variance (ANOVA) and analyses of covariance (ANCOVA) were conducted to (1) illuminate the relationship of the predictor variables on student social studies accountability test results; and (2) provide a context to understanding the results of the hierarchical multiple regression analysis. After these ANOVAs and ANCOVAs were administered, and dummy variables for the nominal categories instructional time configuration and race/ethnicity were created, a hierarchical multiple regression analysis was used to answer the research question.

\section{Results}

\section{Research Question:}

How well do the variables instructional time configuration, gender, and race/ethnicity, while controlling for poverty, predict the academic performance of seventh-grade students on a state-mandated social studies accountability test?

An ANOVA was used to compare instructional time configuration to student social studies accountability test results. Results of the ANOVA showed there was a significant association between instructional time configuration and student social studies accountability test results, $\mathrm{F}(3,24346)=35.72, \mathrm{p}=.000$, partial eta ${ }^{2}$ 
$=.004$. The Levene's test was used to check the assumption that the variances of the four instructional time configurations were equal. Results showed the Levene's test was significant and therefore the assumption of equal variances was violated. Since the Levene's test was significant, a Games-Howell post hoc test was used. Results of the Games-Howell post hoc test revealed there were significant mean differences $(p=.000)$ between all the combinations of the four instructional time configurations with the exception of the difference between the 61-79 minute block all year and the A/B 80-90 minute block all year instructional time configurations $(\mathrm{p}=.083)$. Then, because poverty has been identified as a variable with potential to significantly impact student achievement (Alexander \& Jang, 2020; Anderson, 1993; Baker, 2016; Clotfelter et al., 2009; Fernald et al., 2013; Guo \& Harris, 2000; Harwell, 2018; Kuhfeld et al., 2018; Murnane et al., 2006; Olszewski-Kubilius et al., 2018; Phillips et al., 1998; Turner \& Spain, 2020), an ANCOVA was conducted on the interaction between instructional time configuration and social studies accountability test results using a covariate, Poverty Index, to control for student poverty level. Table 2 shows the result of this analysis.

Table 2: Analysis of Covariance for Student Social Studies Accountability Test Results as a Function of Instructional Time Configuration, Using Poverty Level as a Covariate

\begin{tabular}{lccccc}
\hline Source & $\boldsymbol{d} \boldsymbol{f}$ & $\boldsymbol{M S}$ & $\boldsymbol{F}$ & $\boldsymbol{p}$ & $\begin{array}{c}\text { Partial } \\
\text { eta }^{\mathbf{2}}\end{array}$ \\
\hline InstrTime & 3 & 12119.14 & 5.18 & .001 & .001 \\
Poverty & 1 & 1394527.32 & 596.26 & .000 & .024 \\
InstrTime* Poverty & 3 & 10147.92 & 4.34 & .005 & .001 \\
Error & 24342 & 2338.79 & & & \\
\hline
\end{tabular}

As shown in Table 2, the results of the ANCOVA showed a statistically significant interaction between student social studies accountability test results and instructional time configuration, while controlling for poverty, $\mathrm{F}(3,24342)=5.18, \mathrm{p}=.001$, partial eta ${ }^{2}=.001$. In other words, after controlling for students' poverty level, there is a significant difference among the four instructional time configurations and student social studies accountability test results.

Table 3 presents the means and standard deviations of student social studies accountability test results by instructional time configuration before and after controlling for poverty level.

Table 3: Adjusted and Unadjusted Means and Variability for Student Social Studies Accountability Test Results as a Function of Instructional Time Configuration, Using Poverty Level as a Covariate

\begin{tabular}{lcccccc}
\hline & \multicolumn{4}{c}{ Unadjusted } & \multicolumn{3}{c}{ Adjusted } \\
\hline Instructional Time Configuration & $\boldsymbol{N}$ & $\mathbf{\%}$ & $\boldsymbol{M}$ & $\boldsymbol{S D}$ & $\boldsymbol{M}$ & $\boldsymbol{S E}$ \\
Trad 45-60 min all year & 15660 & 64.3 & 617.23 & 48.95 & 617.56 & 0.39 \\
61-79 min blk all year & 5687 & 23.4 & 621.34 & 51.59 & 620.27 & 0.64 \\
80-90 min blk all year & 1684 & 06.9 & 609.36 & 47.28 & 617.42 & 0.46 \\
A/B 80-90 min blk all year & 1319 & 05.4 & 624.97 & 49.67 & 614.64 & 1.63 \\
\hline
\end{tabular}


As displayed in Table 3, after controlling for students' poverty level, the 61-79 minute block all-year instructional time configuration had the greatest student social studies accountability test results mean (620.27). This configuration was followed by the traditional 45-60 minute all year (617.56) and 80-90 minute block all year (617.42) instructional time configurations. The A/B 80-90 minute block all year instructional time configuration had the greatest student social studies accountability test results mean (624.97) before controlling for poverty, but after adjusting for students' poverty level this configuration had the lowest student social studies accountability test results mean at 614.64.

In addition to poverty, the impact of gender and race/ethnicity on student achievement has been well documented in the literature (Clotfelter et al., 2009; Fryer \& Levitt, 2004, 2006; Holman, 1995; Hull, 2017; Hyde et al., 2008; Kohlhass et al., 2010; Lindberg et al., 2010; Petersen, 2018; Thomas \& Stockton, 2003). A three-way ANOVA was used to help understand the impact students' gender and race/ethnicity, as well as the instructional time configuration used, had on student social studies accountability test results. Table 4 shows the results of the three-way ANOVA.

Table 4: Three-Way Analysis of Variance for Student Social Studies Accountability Test Results as a Function of Instructional Time Configuration, Gender, and Race

\begin{tabular}{lccccc}
\hline Source & $\boldsymbol{d} \boldsymbol{f}$ & $\boldsymbol{M S}$ & $\boldsymbol{F}$ & $\boldsymbol{p}$ & $\begin{array}{c}\text { Partial } \\
\text { eta }^{2}\end{array}$ \\
\hline InstrTime & 3 & 12955.06 & 5.90 & .001 & .001 \\
Gender & 1 & 40951.41 & 18.63 & .000 & .001 \\
Race & 2 & 1079244.18 & 491.06 & .000 & .040 \\
InstrTime*Gender & 3 & 1923.23 & .88 & .453 & .243 \\
InstrTime*Race & 6 & 11691.84 & 5.32 & .000 & .001 \\
InstrTime*Gender*Race & 6 & 2634.33 & 1.20 & .304 & .001 \\
Error & 23814 & & & & \\
\hline
\end{tabular}

As presented in Table 4, the association among the variables instructional time configuration, gender, and ethnicity on student social studies accountability test results was not statistically significant, nor was the association between instructional time configuration and gender. (Because of this, gender would not be used as a predictor variable in the hierarchical multiple regression analysis.) However, there was a statistically significant association between instructional time configuration and ethnicity, $\mathrm{F}(6,23814)=5.32, \mathrm{p}=.000$, partial eta ${ }^{2}=.001$. The Levene's test was used to check the assumption that the variances of the four instructional time configurations and three race/ethnicities (White, Black, and Hispanic) were equal. Results showed the Levene's test was significant and therefore the assumption of equal variances was violated. Since the Levene's test was significant, a Games-Howell post hoc test was used. Results of the Games-Howell post hoc test revealed there were significant mean differences $(\mathrm{p}=.000)$ between the combinations of the four instructional time configurations and White students, White and Black students, and Black and Hispanic students.

An ANCOVA was then used to analyze the interaction between instructional time configuration and race/ethnicity using The Poverty Index data as a covariate to control for student poverty level. Table 5 shows the results of this analysis. 
Table 5: Analysis of Covariance for Student Social Studies Accountability Test Results as a Function of Instructional Time Configuration and Race, Using Poverty Level as a Covariate

\begin{tabular}{lccccc}
\hline Source & $\boldsymbol{d} \boldsymbol{f}$ & $\boldsymbol{M S}$ & $\boldsymbol{F}$ & $\boldsymbol{p}$ & $\begin{array}{c}\text { Partial } \\
\text { eta }^{2}\end{array}$ \\
\hline InstrTime & 3 & 7956.93 & 3.68 & .012 & .001 \\
Race & 2 & 59532.45 & 27.51 & .000 & .000 \\
Poverty & 1 & 131934.14 & 60.98 & .000 & .000 \\
InstrTime* Race* Poverty & 6 & 6644.05 & 3.07 & .005 & .001 \\
Error & 23814 & 2163.73 & & & \\
\hline
\end{tabular}

As shown in Table 5, the result of the ANCOVA showed a statistically significant interaction between instructional time configuration and ethnicity, while controlling for poverty, $\mathrm{F}(6,23814)=3.07, \mathrm{p}=.005$, partial eta $^{2}=.001$.

Table 6 presents the means and standard deviations of White, Black, and Hispanic students on the social studies accountability test results before and after controlling for poverty level.

As shown in Table 6, White students scored significantly higher on the test than Hispanic students, and Hispanic students scored significantly higher on the test than Black students regardless of the instructional time configuration used both before and after controlling for poverty level. In other words, White students scored highest on the test followed by Hispanic and then Black students in all instructional time configurations. Also, Table 6 shows that after controlling for poverty level, there were only slight differences in the test results for White, Black, and Hispanic students-with two exceptions. The mean test score for White students using an A/B 80-90 minute instructional time configuration dropped 9.4 points (from 637.58 to 628.18) after controlling for poverty level. For Black students using an 80-90 minute block configuration, the mean test score rose 8.17 points (from 593.91 to 602.08) after controlling for poverty level. Finally, Table 6 shows that after controlling for poverty level, White and Black students in a 61-79 minute block all-year configuration earned the highest mean test scores; but, Hispanic students earned the highest mean test score using an 80-90 minute block all-year configuration. However, for Hispanic students, the 80-90 minute block all-year configuration also had the largest mean SE (6.64), suggesting relatively high test score variability. 
Table 6: Adjusted and Unadjusted Instructional Time Configuration Means and Variability by Race for Student Social Studies Accountability Test Results, Using Poverty Level as a Covariate

\begin{tabular}{|c|c|c|c|c|c|c|c|c|c|c|c|c|c|c|c|}
\hline \multirow[b]{3}{*}{ Instr Time } & \multicolumn{5}{|c|}{ White } & \multicolumn{6}{|c|}{ Black } & \multicolumn{4}{|c|}{ Hispanic } \\
\hline & \multicolumn{3}{|c|}{ Unadjusted } & \multicolumn{2}{|c|}{ Adjusted } & \multicolumn{3}{|c|}{ Unadjusted } & \multicolumn{2}{|c|}{ Adjusted } & \multicolumn{3}{|c|}{ Unadjusted } & \multicolumn{2}{|c|}{ Adjusted } \\
\hline & $N$ & $M$ & $S D$ & $M$ & $S E$ & $N$ & $M$ & $S D$ & $M$ & $S E$ & $N$ & $M$ & $S D$ & $M$ & $S E$ \\
\hline $\begin{array}{l}\text { Trad } 45^{-} \\
60 \text { min all } \\
\text { year }\end{array}$ & 9430 & 626.98 & 50.01 & 626.05 & .48 & 5143 & 598.35 & 40.31 & 599.56 & .69 & 768 & 610.78 & 43.60 & 610.61 & 1.73 \\
\hline $\begin{array}{l}61-79 \text { min } \\
\text { blk all } \\
\text { year }\end{array}$ & 3084 & 634.71 & 52.46 & 631.55 & .90 & 2203 & 601.78 & 43.66 & 603.90 & 1.03 & 265 & 614.54 & 43.13 & 615.20 & 2.88 \\
\hline $\begin{array}{l}80-90 \\
\text { min blk all } \\
\text { year }\end{array}$ & 908 & 620.10 & 50.24 & 621.53 & 1.60 & 702 & 593.91 & 37.62 & 602.08 & 3.86 & 57 & 619.93 & 50.84 & 620.86 & 6.64 \\
\hline $\begin{array}{l}\text { A/B 80- } \\
90 \text { min blk } \\
\text { all year }\end{array}$ & 860 & 637.58 & 49.44 & 628.18 & 2.22 & 355 & $595 \cdot 57$ & 38.11 & 594.09 & 2.57 & 63 & 614.29 & 41.92 & $613 \cdot 38$ & 5.87 \\
\hline
\end{tabular}


After assessing the relationship among student social studies accountability test results and predictor variables using ANOVAs and ANCOVAs, a hierarchical multiple regression analysis was then used to answer the research question. First, however, dummy variables had to be created for the nominal categories race/ethnicity and instructional time configuration in order to conduct the regression analysis. Two categorical dummy variables, Black and Hispanic, represented student race/ethnicity. For the variable Black, 1 was entered for students who identified themselves as Black and o otherwise. For the variable Hispanic, 1 was entered for students who identified themselves as Hispanic and o otherwise. The reference category for race/ethnicity was White. For instructional time configuration, the variable 61-79 Min, 1 was entered for students in schools using a 61-79 minute block all year instructional time configuration and o otherwise. For the variable 80-90 Min, 1 was entered for students in schools using a 80-90 minute block all year instructional time configuration and o otherwise. For the variable A/B 80-9o Min, 1 was entered for students in schools using an A/B 80-90 minute block all-year instructional time configuration and o otherwise. The reference category for instructional time configuration was 45-6o Min.

After creating the dummy variables, a hierarchical multiple regression analysis was conducted to investigate how well instructional time configuration and race/ethnicity, while controlling for poverty (using the Poverty Index), predicted the academic performance of seventh-grade students on a state-mandated social studies accountability test. (The assumptions of linearity, normally distributed errors, and uncorrelated areas were checked and met.) Means and standard deviations for student social studies accountability test results and predictor variables are presented in Table 7.

Table 7: Means and Standard Deviations for Student Social Studies Accountability Test Results and Predictor Variables $(N=24582)$

\begin{tabular}{lcc}
\hline Variable & M & SD \\
Social Studies Test Results & 617.95 & 49.57 \\
Predictor variable & & \\
1. Poverty Index & 62.88 & 18.39 \\
2. Black & .34 & .47 \\
3. Hispanic & .05 & .21 \\
4. 61-79 Min & .23 & .42 \\
5. 80-90 Min & .07 & .25 \\
6. A/B 80-90 Min & .05 & .23 \\
\hline
\end{tabular}

Note. ${ }^{a}$ Reference category for race/ethnicity variables is White; breference category for schedule configuration variables is $45-60$ Min.

Additionally, Table 8 shows the results of the hierarchical multiple regression analysis.

As displayed in Table 8, results of the unstandardized beta coefficients show that for each point students rate on the Poverty Index, they lose approximately .4 point on the social studies accountability test. Also, results of the unstandardized beta coefficients show Black students earned 26 points less and Hispanic students earned 16 points less than the reference category (White students) on the social studies accountability test. With regards to the remaining predictor variable, instructional time configuration, the unstandardized beta coefficients show students in 61-79 minute block all-year configurations earn about five points more and students in 80-90 minute block all-year configurations earn about one point less than the reference category 
(traditional 45-60 minute all year) on the social studies accountability test. This information, taking into account SEB, coincides with the results of the ANOVA and ANCOVA.

Table 8: Hierarchical Multiple Regression Analysis Predicting Student Social Studies Accountability Test Results From Race/Ethnicity and Instructional Time Configuration, When Controlling for Poverty $(N=24582)$

\begin{tabular}{|c|c|c|c|c|c|}
\hline Variable & $\mathbf{B}$ & SEB & $\beta$ & R2 & $\Delta \mathbf{R 2}$ \\
\hline Step 1 & & & & .05 & .05 \\
\hline Poverty Index & -.59 & .02 & $-.22^{*}$ & & \\
\hline Constant & 655.19 & 1.10 & & & \\
\hline Step 2 & & & & .11 & .06 \\
\hline Poverty Index & -.41 & .02 & $-.15^{*}$ & & \\
\hline Black ${ }^{a}$ & -26.48 & .66 & $-.25^{*}$ & & \\
\hline Hispanic $^{a}$ & -16.20 & 1.43 & $-.07^{*}$ & & \\
\hline 61-79 $\mathrm{Min}^{\mathrm{b}}$ & 4.96 & .73 & $.04^{*}$ & & \\
\hline 80-90 Min ${ }^{\mathrm{b}}$ & -1.05 & 1.21 & -.01 & & \\
\hline A/B 80-9o Min & .14 & 1.36 & .00 & & \\
\hline Constant & 652.51 & 1.13 & & & \\
\hline
\end{tabular}

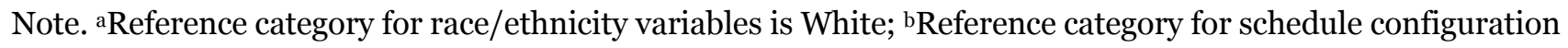
variables is $45^{-60}$ Min.

$\mathrm{R} 2=.11, \mathrm{~F}(6,24576)=496.30, \mathrm{p}<.001$

${ }^{*} \mathrm{p}<.001$

Additionally, regarding predictability of students' academic performance on the social studies accountability test (the focus of the research study), Table 8 shows that when the variable poverty was entered alone, it significantly predicted student social studies accountability test results, $\mathrm{F}(1,24581)=1247.26, \mathrm{p}=.000$, adjusted R2 = .05. However, as indicated by the R2, only $5 \%$ of the variance in student social studies accountability test results could be predicted by knowing the student's poverty level. When the variables instructional time configuration and race/ethnicity were added, they significantly improve the prediction, $\Delta \mathrm{R} 2=.06, \mathrm{~F}(6,24576)=329.44, \mathrm{p}=.000$. The entire group of variables significantly predicted student social studies accountability test results, $\mathrm{F}(6,24576)=496.30, \mathrm{p}=.000$, adjusted $\mathrm{R} 2=.11$. This is a small effect (Cohen, 1988).

The standardized beta weights and significant values, presented in Table 8, indicate which variables contribute most to predicting student social studies accountability test results when poverty, instructional time configuration, and race/ethnicity are entered together as predictors. Results show the variables Black (-.25), poverty (-.15), and Hispanic (-.07) have the highest beta weights and are significant negative predictors of student social studies accountability test results (score decrease). Only the variable 61-79 minute block allyear instructional time configuration is significant and has a beta weight (.04) indicating it is a positive predictor of student social studies accountability test results (score increase). 
Vogler et al., 2020

\section{Discussion}

\section{Research Question}

How well do the variables instructional time configuration, gender, and race/ethnicity, while controlling for poverty, predict the academic performance of seventh-grade students on a state-mandated social studies accountability test?

Results of an ANOVA comparing instructional time configuration by student social studies accountability test results, and an ANCOVA using the Poverty Index to control for student poverty level, found a significant difference between instructional time configuration and student social studies accountability test results: Students in schools using a 61-79 minute block all year schedule configuration earned significantly higher student social studies accountability test results than students in schools using a traditional $45^{-60}$ minute allyear schedule configuration or the sample's two other frequently used types of block scheduling configurations. This finding supports previous research concluding that students in block schedules perform better on standardized tests than traditionally scheduled students (Arnold, 2002; Cobb et al., 1999; Evans et al., 2002; Gullatt, 2006; Hess et al., 1999; Mattox et al., 2005, Payne \& Jordan, 1996; Queen et al., 1996; Rice et al., 2002) and refutes findings of previous studies that either conclude there are no significant differences in student test performance with regard to the scheduling configuration used at the school (Duel, 1999; Lare et al., 2002; Snyder, 1997; Veal \& Schreiber, 1999) or traditionally scheduled students outperform blockscheduled students on standardized tests (Brake, 2000; Gruber \& Onwuegbuzie, 2001; Knight et al., 1999; Lawrence \& McPherson, 2000; Pisapia \& Westfall, 1997).

However, results seem to indicate that there is a limit to the effectiveness of block scheduling on students' academic performance. After controlling for student poverty level, the instructional time configurations with the greatest amount of per period class time (80-90 minute block all-year and A/B 80-90 minute block allyear schedules) had the lowest student performance levels, while the instructional time configurations with the least amount per period class time (61-79 minute block all year and traditional 45-60 minute all year schedules) had the highest student performance levels. While the research literature addressing the relationship of achievement and instructional time configuration impact is sparse, especially with regard to middle-level social studies testing scenarios, the findings of this study support those of similar studies (Gainey \& Brucato, 1999; Lewis et al., 2003). Evidence that longer instructional periods fail to adequately support average attention spans or the retention of general knowledge in core areas (Gould, 2003; Gullatt, 2006; Wilson \& Stokes, 2000) supports this study's finding that the schedules with the greatest amount of instructional time allocated to social studies (80-90 minute block all-year and the A/B 80-90 minute block all-year schedules) have the lowest student social studies accountability test results.

After addressing the relationship between instructional time configuration and student social studies accountability test results, we then focused our attention on the variables gender and race/ethnicity. A threeway ANOVA comparing instructional time configuration by the sample student population's gender and race/ethnicity to student social studies accountability test results was conducted. This was followed by an ANCOVA addressing the interaction among instructional time configuration, gender, and race/ethnicity using the Poverty Index to control for student poverty level. Results showed a significant interaction among the variables instructional time configuration, ethnicity, and student social studies accountability test results. White students, both before and after controlling for poverty, had significantly higher social studies accountability test results than Hispanic students, and Hispanic students had significantly higher social studies accountability test results than Black students regardless of the instructional time configuration used at the school. This result is consistent with general research findings that subgroup membership impacts achievement (Burchinal et al., 2011; Fryer \& Levitt, 2004; Holman, 1995; Kohlhaas et al., 2010; Paschall et al., 
2018; Thomas \& Stockton, 2003), and is consistent with specific research addressing the race/ethnicity academic achievement gap (Clotfelter et al., 2009; Hemphill \& Vanneman, 2011; Hull, 2017; Phillips \& Chin, 2004; Reardon \& Galindo, 2009; Reardon \& Robinson, 2008).

Additionally, results showed White, Hispanic, and Black students had significantly higher social studies accountability test results in the instructional time configurations meeting for longer periods of time than the traditional 45-60 minute all-year configuration. More specifically, and taking into account the uncertainty caused by the relatively high mean SE of Hispanic students using an 80-90 minute block all-year configuration, White, Black, and possibly Hispanic students in a 61-79 minute block all-year configuration earned the highest mean test scores. This finding coincides with previous research showing students perform better in block schedules with longer, concentrated periods of time than a traditional instructional time configuration (Candy \& Rettig, 1995; Carroll, 1994; Childers \& Ireland, 2005; Evans, 2005; Fisher \& Frey, 2007; Gill, 2011; Gullatt, 2006). Also, research on social studies instruction shows that longer class periods allow teachers increased opportunities for group activities and in-class projects (Bryant \& Bryant, 2000; DiBiase \& Queen, 1999; Hamdy \& Urich, 1998; Johnson \& Johnson, 1989; Rofes, 2001; Wilson \& Stokes, 2000) and to abandon lectures and utilize strategies more compatible with individualized instruction (Gullatt, 2006; Slavin et al., 1989; Wilson \& Stokes, 2000). However, results also revealed there was no significant association either between instructional time configurations and gender or among the variables instructional time configuration, gender, and race/ethnicity. Therefore, gender was not used as a predictor variable in the hierarchical multiple regression analysis.

Lastly, a hierarchical multiple regression analysis was conducted. Results showed that when controlling for poverty, the variables instructional time configuration and race/ethnicity were significant, explaining $11 \%$ of the variation in student social studies accountability test results. This, according to Cohen (1988), was a small effect. Additionally, results showed the variables Black (-.25), poverty (-.15), and Hispanic (-.07) had the highest beta weights and were significant negative predictors of student social studies accountability test results (score decrease). Only one variable in the model, 61-79 minute block all-year instructional time configuration, was significant and had a beta weight (.04) indicating it was a positive predictor of student social studies accountability test results (score increase).

Results of the hierarchical multiple regression analysis also indicated poverty was a significant predictor of accountability test results. However, according to the model, the strongest significant predictor of student social studies accountability test results was race/ethnicity. The model's unstandardized beta coefficients show Black students earned 26 points less and Hispanic students earned 16 points less than White students on the social studies accountability test. Finally, with regard to the remaining predictor variable, instructional time configuration, only 61-79 minute block all year was significant. The unstandardized beta coefficient shows, and confirmed using an ANOVA and ANCOVA, students in a 61-79 minute block all-year instructional time configuration earned at least five points more on the social studies accountability test than students engaged in any other instructional time configuration.

\section{Limitations}

The scope of this study was limited to South Carolina public middle-level schools meeting the criteria for inclusion in this study and whose principal completed the survey instrument. Only schools designated as public middle-level schools that contained grade seven were eligible for inclusion in the target population. Schools classified as charter schools and schools with multiple elementary and/or secondary grades were not included. Because South Carolina assesses social studies state-mandated test results as part of a school's report card calculation, caution must be used in making generalizations about social studies achievement in states that either do not assess social studies or do not assess it at the middle-level. 
Further, because the results of this study considered instructional time configurations and achievement in social studies only for the seventh-grade, results could not be generalized beyond this grade level. Also, because this was an initial study, it only considered how instruction time is configured over the course of a school year. Additionally, the analysis was limited to the most commonly used instructional time configurations. Finally, data was only available at the school level. Therefore, it did not address intervening variables focusing on the unique attributes of classroom teachers such as differences in how time was used within schedules/classrooms, instructional strategies, quality, experience and training, skill in teaching social studies, or the amount of engaged learning time.

\section{Conclusion, Recommendation, and Future Research}

The study was designed to answer the research question: How well do the variables instructional time configuration, gender, and race/ethnicity, while controlling for poverty, predict the academic performance of seventh-grade students on a state-mandated social studies accountability test? Results of a hierarchical multiple regression analysis showed the variables instructional time configuration, poverty and race/ethnicity were significant, explaining $\mathbf{1 1 \%}$ of the variation in student social studies accountability test results; and, according to Cohen (1988), this was a small effect.

Additionally, results showed the variables Black (-.25), poverty (-.15), and Hispanic (-.07) had the highest beta weights and were significant negative predictors of student social studies accountability test results (score decrease); Black students earned 26 points less and Hispanic students earned 16 points less than White students on the test. Only one variable in the model, 61-79 minute block all-year instructional time configuration, was significant and had a beta weight (.04) indicating it was a positive predictor of student social studies accountability test results (score increase). Students in a 61-79 minute block all-year instructional time configuration earned at least five points more on the social studies accountability test than students engaged in any other instructional time configuration.

Based on the results of the model, and existing literature, administrators might consider adopting a 61-79 minute block all-year instructional time configuration. This configuration, or something similar, seems to provide teachers with increased in-class instructional opportunities while maintaining student attention and retention of knowledge.

Although this study has provided valuable information about the predictability the variables instructional time (scheduling) configuration, race/ethnicity, and poverty have on students' social studies test performance, many questions still remain. For example, what additional variables could help explain more of the variation in social studies accountability test results? What are teachers' perspectives regarding traditional and block instructional time configurations and student achievement on state-mandated tests? What differences are there in the instructional practices used by teachers in meeting state standards in block and traditional instructional time configurations? What differences are there in how teachers in block and traditional time configurations are addressing the race/ethnicity achievement gap? Finally, what differences are there in students' grades and state-mandated testing performance in block instructional time configurations compared with the traditional time configuration? 


\section{References}

Abrams, L. M., Pedulla, J. J., \& Madaus, G. R. (2003). Views from the classroom: Teachers' opinions of statewide testing programs. Theory Into Practice, 42, 1-29. https://doi.org/10.1207/s15430421tip4201_4

Alberti, S. (2012/2013). Making the shifts. Educational Leadership, 7O(4), 24-27.

Alexander, N. A., \& Jang, S. T. (2020). Policy, poverty, and student achievement: An exploration of the impact of state policies. Educational Policy, 34(4), 674-704. https://doi.org/10.1177/0895904818802114

Anderson, J. (1993). Re-examining the relationship between school poverty and student achievement. ERS Spectrum, 11(2), 21-31.

Arnold, D. E. (2002). Block schedule and traditional schedule achievement: A comparison. NASSP Bulletin, 86(630), 42-53. https://doi.org/10.1177/019263650208663006

Baker, B. D. (2016). Does money matter in education? Albert Shanker Institute.

Bailey, G., Shaw, E. L., \& Hollifield, D. (2006). The devaluation of social studies in the elementary grades. The Journal of Social Studies Research, 30(2), 18-29.

Bevevino, M. M., Snodgrass, D. M., Adams, K. M., \& Dengel, J. A. (1999). An educator's guide to block scheduling. Allyn \& Bacon.

Brake, N. (2000, November 15-17). Student course-taking delivered through a high school block schedule: The relationship between the academic core and student achievement [Paper presentation]. MidSouth Educational Research Association, Bowling Green, KY, United States.

Bryant, C., \& Bryant, R. (2000). Social studies in the block schedule: A model for effective lesson design. The Social Studies, 91(1), 9-16. https://doi.org/10.1080/00377990009602435

Burchinal, M., McCartney, K., Steinberg, L., Crosnoe, R., Friedman, S. L., McLoyd, V., \& Pianta, R. (2011). Examing the Black-White achievement gap among low-income children using the NICHD study of early child care and youth development. Child Development, 82(5), 1404-1420.

Burroughs, S., Groce, E., \& Webeck, M. L. (2005). Social studies education in the age of testing and accountability. Educational Measurement: Issues and Practice, 24(3), 13-20.

Canady, R. L., \& Rettig, M. D. (1995). Block scheduling, a catalyst for change. Larchmont.

Canady, R. L., \& Rettig, M. D. (1996). Block scheduling: What is it? Why do it? How do we harness its potential to improve teaching and learning? In R. L. Canady \& M. D. Rettig (Eds.), Teaching on the block (pp. 1-27). Eye on Education.

Canady, R. L., \& Rettig, M. D. (2000). The effects of block scheduling. School Administrator, 56(3), 14, 18-20.

Carroll, J. M. (1994). The Copernican plan evaluated: The evolution of a revolution. Phi Delta Kappan, 76, 104-110, 112-113.

Childers, G., \& Ireland, R. (2005). Mixing block and traditional scheduling. Education Digest, 71(3), 43-49.

Clotfelter, C. T., Ladd, H. F., \& Vigdor, J. L. (2009). The academic achievement gap in grades 3 to 8. Review of Economics and Statistics, 91(2), 398-419.

Cobb, R. B., Abate, S., \& Baker, D. (1999). Effects on students of a 4 x 4 junior high school block scheduling program. Education Policy Analysis Archives, 7(3). https://doi.org/10.14507/epaa.v7n3.1999

Cohen, J. (1988). Statistical power analysis for the behavioral sciences (2nd ed.). Lawrence Earlbaum Associates. 
Daniel, L. (2007). Research summary: Flexible scheduling. http://www.amle.org/Portals/o/pdf/research_summaries?Flexible_Scheduling.pdf

Davis, J. E., \& Jordan, W. J. (1996). The effects of school context, structure, and experiences on African American males in middle school performance differences between African American and nonHispanic Whites. American Journal of Education, 97, 534-567.

DiBiase, W., \& Queen, J. A. (1999). Middle school social studies on the block. The Clearing House, 72(6), 377384. https://doi.org/10.1080/00098659909599428

Duel, L. S. (1999). Block scheduling in large, urban high schools: Effects on academic achievement, student behavior, and staff perceptions. High School Journal, 83(1), 14-25.

Evans, R. (2005). Reframing the achievement gap. Phi Delta Kappan, 86(8), 582-589.

Evans, W., Tokarczyk, J., Rice, S., \& McCray, A. (2002). Block scheduling: An evaluation of outcomes and impact. Clearing House, 75(6), 319-323. https://doi.org/10.1080/00098650209603964

Every Student Succeeds Act (ESSA) of 2015, Public Law No. 114-95, S.1177, 114th Cong. (2015). http:/www.congress.gov/114/plaws/publ95/PLAW-114publ95.pdf

Fernald, A., Marchman, V. A., \& Weisleder, A. (2013). SES differences in language processing skill and vocabulary are evident at 18 months. Developmental Science, 16, 234-248.

Fisher, D., \& Frey, N. (2007). A tale of two middle schools: The difference in structure and instruction. Journal of Adolescent and Adult Literacy, 51(3), 204-211. https://doi.org/10.1598/JAAL.51.3.1

Ford, D. (1992). The American achievement ideology as perceived by urban African American students: Explorations by gender and academic program. Urban Education, 27, 196-211.

Fryer, R. G., \& Levitt, S. D. (2004). Understanding the Black-White test score gap in the first two years of school. Review of Economics and Statistics, 86(2), 447-464. https://doi.org/10.1162/003465304323031049

Fryer, R. G., \& Levitt, S. D. (2006). The Black-White test score gap through third grade. American Law and Economics Review, 8(2), 249-281.

Gainey, D. D., \& Brucato, J. M. (1999). Questions \& answers about block scheduling: An implementation guide. Eye on Education.

Gill, W. A. (2011). Middle school A/B block and traditional scheduling: An analysis of math and reading performance by race. NASSP Bulletin, 95(4), 281-301. https://doi.org/10.1177/0192636511420998

Goodlad, J. I. (1984). A place called school: Prospects for the future. McGraw-Hill.

Gould, P. F. (2003, May 7). Scheduling choice. Education Week, 22(34), 34-35.

Gruber, C., \& Onwuegbuzie, A. J. (2001). Effects of block scheduling on academic achievement among high school students. High School Journal, 84(4), 32-42.

Gullatt, D. E. (2006). Block scheduling: The effects on curriculum and student productivity. NASSP Bulletin, 9o(3), 250-266. https://doi.org/10.1177/0192636506292382

Guo, G., \& Harris, K. M. (2000). The mechanisms mediating the effects of poverty on children's intellectual development. Demography, 37(4), 431-448.

Hackmann, D. G. (2002). Block scheduling for the middle-level: A cautionary tale about the best features of secondary school models. Middle School Journal, 33(4), 22-28.

Hackmann, D. G., \& Valentine, J. W. (1998). Designing an effective middle-level schedule. Middle School Journal, 29(5), 313. 
Hamdy, M., \& Urich, T. R. (1998). Principals' perceptions of block scheduling. American Secondary Education, 26(3), 8-12.

Harwell, M. (2018). Don't expect too much: The limited usefulness of common SES measures and a prescription for change. National Education Policy Center.

Heafner, T. L. (2018). More social studies? Examing instructional policies of time and testing in elementary school. The Journal of Social Studies Research, 42, 229-237.

Hemphill, F. C., \& Vanneman, A. (2011). Achievement gaps: How Hispanic and White students in public schools perform in mathematics and reading on the National Assessment of Educational Progress (NCES 2011-459). National Center for Educational Statistics, Institute of Education Sciences, U.S. Department of Education. Washington, DC.

Hess, C., Wronkovich, M., \& Robinson, J. (1999). Measure outcomes of learning under block scheduling. NASSP Bulletin, 83(611), 87-95.

Holman, L. J. (1995, April). Impact of ethnicity, class, and gender on achievement of border area students on high stakes examination [Paper presentation]. American Educational Research Association, San Francisco, CA, United States.

Hottenstein, D. S. (1998). Intensive scheduling: restructuring America's secondary schools through time management. Corwin Press.

Hong, H., \& Hamot, G. E. (2020). Differential effects of state testing policies and school characteristics on social studies educators' gate-keeping autonomy: A multilevel model. Theory and Research in Social Education, 48(1), 74-100.

Houser, N. O., Krutka, D. G., Roberts, P. R., Pennington, K., \& Coerver, N. F. (2017). Navigating the reform: Accountability culture in Oklahoma social studies. Theory and Research in Social Education, 45(1), 7-42.

Hull, M. C. (2017). The academic progress of Hispanic immigrants. Economics of Educational Review, 57, 91-110.

Hyde, J. S., Lindberg, S. M., Linn, M. C., Ellis, A. B., \& Williams, C. C. (2008). Gender similarities characterize math performance. Science, 321(5888), 494-495.

Johnson, D. W., \& Johnson, R. (1989). Cooperation and competition: Theory and research. Interaction Book Co.

Kavanagh, K. M., \& Fisher-Ari, T. R. (2018) Curricular and pedagogical oppression: Contradictions within the juggernaut accountability trap. Educational Policy, 54(2), 1-29.

Knight, S. L., DeLeon, N. J., \& Smith, R. G. (1999). Using multiple data sources to evaluate an alternative scheduling model. High School Journal, 83(1), 1-13.

Kohlhaas, K., Lin, H., \& Chu, K. (2010). Disaggregated outcomes of gender, ethnicity, and poverty on fifthgrade science performance. National Middle School Association: RMLE Online Research in Middlelevel Education, 33(7), 1-12.

Kuhfeld, M., Gershoff, E., \& Paschall, K. (2018). The development of racial/ethnic and socioeconomic achievement gaps during the school years. Journal of Applied Developmental Psychology, 57, 62-73.

Lare, D., Jablonski, A. M., \& Salvaterra, M. (2002). Block scheduling: Is it cost-effective? NASSP Bulletin, 86(630), 54-71. https://doi.org/10.1177/019263650208663007

Lawrence, W. W., \& McPherson, D. D. (2000). A comparative study of block scheduling and traditional scheduling on academic achievement. Journal of Instructional Psychology, 27(3), 178-182.

Leming, J. S., Ellington, L., \& Schug, M. (2006). The state of social studies: A national random survey of elementary and middle school social studies teachers. Social Education, 7o(5), 322-327. 
Lewis, C. W., Cobb, R. B., Winokur, M., Leech, N., Viney M., \& White, W. (2003). The effects of full and alternative day block scheduling on language arts and science achievement in a junior high school. Education Policy Analysis Archives, 11(41). http://epaa.asu.edu/epaa/v11n41/

Lindberg, S., Hyde, J., Petersen, J., \& Linn, M. (2010). New trends in gender and math performance: A metaanalysis. Psychological Bulletin, 136(6), 1123-1135.

Lintner, T. (2006). Social studies (still) on the back burner: Perceptions and practices of K-12 social studies instruction. Journal of Social Studies Research, 30(1), 3-8.

Madaus, G., \& Russell, M. (2009/2010). Paradoxes of high-stakes testing. Journal of Education, 19o(1/2), 21-30. https://doi.org/10.1177/0022057410190001-205

Mattox, K., Hancock, D., \& Queen, J. A. (2005). The effect of block scheduling on middle school students' mathematics achievement. NASSP Bulletin, 89(642), 3-13.

Mickelson, R. A., \& Greene, A. D. (2006). Connecting pieces of the puzzle: Gender differences in Black middle school students' achievement. The Journal of Negro Education, 75(1), 34-48.

Mullen, J. \& Woods, J. R. (2018). 50-state comparison: State summative assessments. http://www.ecs.org/50-state-comparison-state-summative-assessment

Murnane, R. J., Willett, J. B., Bub, K. L., McCartney, K., Hanushek, E., \& Maynard, R. (2006). Understanding trends in the Black-White achievement gaps during the first years of school. Brookings-Wharton Papers on Urban Affairs (pp. 97-135).

National Commission on Excellence in Education. (1983). A nation at risk: The imperative for educational reform. Author.

National Education Commission on Time and Learning. (1994). Prisoners of time: Report of the National Education Commission on Time and Learning. Government Printing Office.

No Child Left Behind Act, Pub. L. 107-110, 20 U.S.C. 6301, 115 Stat. 1425 (2002).

Nunnally, J. C., \& Bernstein, I. H. (1994). Psychometric theory (3rd ed.). McGraw-Hill.

Olszewski-Kubilius, P., \& Corwith, S. (2018). Poverty, academic achievement, and giftedness: A literature review. Gifted Child Quarterly, 62(1), 37-55.

Pace, J. (2012). Teaching literacy through social studies under No Child Left Behind. Journal of Social Studies Research, 36, 329-358.

Paschall, K. W., Gershoff, E. T., \& Kuhfeld, M. (2018). A two decade examination of historical race/ethnicity disparities in academic achievement by poverty status. Journal of Youth and Adolescence, 47, 11641177. https://doi.org/10.1007/s10964-017-0800-7

Pascopella, A. (2005). Staying alive: Social studies in elementary schools. Social Studies and the Young Learner, 17(3), 30-32.

Payne, D., \& Jordan, M. M. (1996). The evaluation of a high school block schedule: Convergence of teacher and student data. American Secondary Education, 25(2), 16-19.

Pedulla, J. J., Abrams, L. M., Madaus, G. F., Russell, M. K., Ramos, M. A., \& Miao, J. (2003). Perceived effects of state-mandated testing programs on teaching and learning: Findings from a national survey of teachers. Chestnut Hill, MA: Center for the Study of Testing, Evaluation, and Educational Policy, Boston College. 
Vogler et al., 2020

Petersen, J. (2018). Gender difference in verbal performance: A meta-analysis of United States state performance assessments. Educational Psychology Review, 30, 1269-1281.

https://doi.org/10.1007/s10648-018-9450-x

Phillips, M. \& Chin, T. (2004). School inequality: What do we know? In K. Neckerman (Ed.), Social inequality, Russel Sage Foundation.

Phillips, M., Crouse, J., \& Ralph, J. (1998). Does the Black-White test score gap widen after children enter school? In C. Jencks, \& M. Phillips (Eds.). The Black-White test score gap (pp. 229-272). Brookings Institution Press.

Pisapia, J., \& Westfall, A. L. (1997). Alternative high school scheduling: Student achievement and behavior. Metropolitan Educational Research Consortium.

Powell, A. G., Farrar, E., \& Cohen, D. K. (1985). The shopping mall high school: Winners and losers in the educational marketplace. Houghton Mifflin.

Queen, J. A., Algozzine, B., \& Eaddy, M. (1996). The success of 4 x 4 block scheduling in the social studies. Social Studies, 87(6), 249-253. https://doi.org/10.1080/00377996.1996.10114496

Reardon, S. F., \& Galindo, C. (2009). The Hispanic-White achievement gap in math and reading in the elementary grades. American Educational Research Journal, 46(3), 853-891.

Reardon, S. F., \& Portilla, X. A. (2015). Recent trends in socioeconomic and racial school readiness gaps at kindergarten entry. CEPA Working Paper No. 15-02. https://cepa.stanford.edu/sites/default/files/wp15-02-v201606 o.pdf

Reardon, S. F., \& Robinson, J. P. (2008). Patterns and trends in racial/ethnic and socioeconomic academic achievement gaps. In H. F. Ladd \& E. B. Fiske (Eds.), Handbook of research in education finance and policy (pp. 499-518). Routledge.

Reeves, R., Rodrigue, E., \& Kneebone, E. (2016). Five evils: Multidimensional poverty and race in America. https://www.brookings.edu/wpcontent/uploads/2016/06/reeveskneebonerodrigue multidimensionalpoverty fullpaper.pdf

Rice, J. K., Croninger, R. G., \& Roellke, C. F. (2002). The effect of block scheduling high school mathematics courses on student achievement and teachers' use of time: Implications for educational productivity. Economics of Education Review, 21(599), 1-19.

Rofes, E. (2001, April). How do students and teachers experience block scheduling? [Paper presentation]. American Educational Research Association, Seattle, WA, United States.

Segail, A. (2003). Teacher's perceptions of the impact of state-mandated standardized testing: The Michigan educational assessment program (MEAP) as a case study of consequences. Theory and Research in Social Education, 31(3), 287-325.

Slavin, R. E., Karweit, N. L., \& Madden, N. A. (1989). Effective programs for students at risk. Allyn \& Bacon.

South Carolina Department of Education. (2009a). Palmetto assessment of state standards (PASS) social studies test blueprint for grades $3-8$.

https://web.archive.org/web/20091017163613/http://ed.sc.gov/agency/Accountability/Assessment/ documents/PASS SSBlueprint10 06 09.pdf

South Carolina Department of Education. (2009b). Technical documentation for the 2009 palmetto assessment of state standards of writing, English language arts, mathematics, science, and social studies. https://ed.sc.gov/tests/assessment-information/archives/technical-reports/ 
Snyder, D. (1997, October). 4-block scheduling: A case study of data analysis of one high school after two years [Paper presentation]. Mid-West Educational Research Association Annual Meeting, Chicago, IL, United States.

Texas Education Agency Office of Policy Planning and Research: Division of Research and Evaluation. (1999). Block scheduling in Texas public high schools. Author. http://www.tea.state.tx.us/research/pdfs/prr13.pdf

Thomas, J., \& Stockton, C. (2003). Socioeconomic status, race, gender, \& retention: Impact on student achievement.

http://citeseerx.ist.psu.edu/viewdoc/download?doi=10.1.1.515.2840\&rep=rep1\&type $=$ pdf

Thompson, J. P., \& Suarez, G. A. (2015). Exploring the racial wealth gap using the survey of consumer finances (finance and economics discussion series 2015-076). Board of Governors of the Federal Reserve System. https://doi.org/10.17016/FEDS.2015.076

Turner, E. O., \& Spain, A. K. (2020). The multiple meanings of (in)equity: Remaking school district tracking policy in an era of budget cuts and accountability. Urban Education, 55(5), 783-812. https://doi.org/10.1177/0042085916674060

VanFossen, P. J. (2005). "Reading and math take so much of the time...": An overview of social studies instruction in elementary classrooms in Indiana. Theory and Research in Social Education, 33(3), $376-403$.

Veal, W. R., \& Schreiber, J. (1999). Block scheduling effects on a state-mandated test of basic skills. Education Policy Analysis Archives, 7(29), 1-14.

Vogler, K. E. (2003). Where does social studies fit in a high-stakes testing environment? The Social Studies, 94(5), 207-211. https://doi.org/10.1080/00377990309600208

Vogler, K. E., \& Virtue, D. (2007). “Just the facts, ma'am”: Teaching social studies in the era of standards and high-stakes testing. The Social Studies, 98(2), 54-58. https://doi.org/10.3200/TSSS.98.2.54-58

von Zastrow, C., \& Janc, H. (2004). Academic atrophy: The condition of the liberal arts in America's public schools. https://www.americansforthearts.org/sites/default/files/AcademicAtrophy 2.pdf

Wilson, J., \& Stokes, L. C. (2000). Students' perceptions of the effectiveness of block versus traditional scheduling. American Secondary Education, 28(3), 3-12.

Zamosky, L. (2008). Social studies: Is it history? District Administration, 44(3), 46-48, 50.

Zepeda, S. J., \& Mayers, R. S. (2006). An analysis of research on block scheduling. Review of Educational Research, 76(1), 137-170.

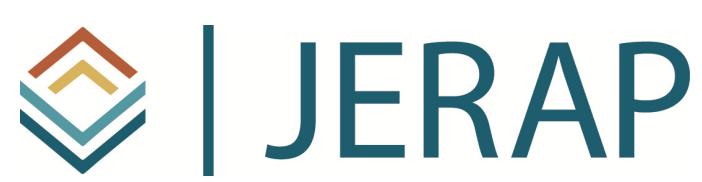

The Journal of Educational Research and Practice is a peerreviewed journal that provides a forum for studies and dialogue about developments and change in the field of education and learning. The journal includes research and related content that examine current relevant educational issues and processes. The aim is to provide readers with knowledge and with strategies to use that knowledge in educational or learning environments. JERAP focuses on education at all levels and in any setting, and includes peer-reviewed research reports, commentaries, book reviews, interviews of prominent individuals, and reports about educational practice. The journal is sponsored by the Richard W. Riley College of Education and Leadership at Walden University, and publication in JERAP is always free to authors and readers. 